\title{
Om hemlösa kvinnor i Köpenhamn
}

\author{
MARGARETHA JÄRVINEN
}

\begin{abstract}
I artikeln skall de hemlösas kvinnornas situation beskrivas och analyseras. Kvinnorna är nästan helt osynliga $i$ tidigare hemlöshetsundersökningar. Håller det påatt ske en feminisering av hemlösheten? Hur ser livsvillkoren ut för de kvinnliga hemlösa? Vilken behandling fär de?
\end{abstract}

Under de senaste tio åren har man i många västländer talat om "en ny hemlöshet«. Diskussionen om de nya hemlösa startade $i$ USA för ca femton år sedan och har senare spridit sig till andra länder. Danmark är kanske det nordiska land som mest okritiskt tagit över retoriken om en ny hemlöshet - en hemlöshet som blivit allt större och som omfattar andra grupper än tidigare, häribland kvinnor, ungdomar och psykiskt sjuka.

Jag skall i denna artikel diskutera en av dessa nya grupper av hemlösa, nämligen kvinnorna. Jag skall redogöra för en undersökning om hemlösa kvinnor i Köpenhamn

Margaretha Järvinen är pol.dr., lektor vid Sociologisk Institut, Københavns Universitet. Hennes doktorsavhandling (Prostitutionen i Helsingfors en studie $i$ kvinnokontroll) publicerades år 1991. MJ har i många år arbetat med missbruksforskning och med forskning kring socialt utslagna grupper. Hon har nyligen avslutat ett forskningsprojekt om hemlösa kvinnor och håller f.n. på med en studie om »tunga missbrukare« i Köpenhamn. som jag har arbetat med under de senaste åren. Med "hemlösau avses här - helt pragmatiskt - personer som övernattar på s.k. § 105 institutioner ${ }^{1}$. En central del av det empiriska materialet i undersökningen utgörs av djupintervjuer med 40 kvinnor, som har varit i kontakt med hemlöshetsinstitutioner. Dessutom har jag intervjuat personal på dessa institutioner. Sammanlagt har 46 personalrepresentanter på 30 olika institutioner deltagit i undersökningen, speciellt föreståndare och/eller socialarbetare på $\S 105$-institutionerna i Köpenhamns kommun.

1 Bistandslovens § 105: „Amtsrådet skal sørge for, at der er mulighed for optagelse i forsorgshjem og andre institutioner for personer, der er hjemløse eller ikke kan tilvænne sig det almindelige samfundsliv. Forsorgshjem og tilsvarende institutioner kan oprettes og drives af en eller flere amtskommuner eller som selvejende institutioner, med hvilke amtsrådet indgår overenskomst». 
Diskussionen om en ny hemlöshet i Danmark har ett intressant samband med personalstrukturen på institutionerna. 1980-talet var nämligen den period då personalen fick en klar professionell profil. Från att ha varit en sektor dominerad av icke utbildad personal, har $\S 105$ området så småningom fått in nya yrkesgrupper, speciellt socialpedagoger. Nya personalgrupper tenderar att skapa nya problemdefinitioner (jfr. Dear \& Wolch 1987) - så också bland dem som arbetar med hemlösa. Genom debattinlägg och uttalanden i massmedia har institutionernas representanter bidragit till att skapa den offentliga bilden av nya - och ständigt mera resurskrävande - hemlöshetsproblem.

Den teoretiska utgångspunkt jag har valt i min undersökning är att jag har analyserat hemlöshet som en social konstruktion, dvs. ett relativt, socialt och kulturellt fenomen, ett socialt fält som är wöppet«. Trots att hemlöshetsbegreppet omedelbart kan synas okomplicerat - de flesta av oss har väl en uppfattning om hur en person som saknar tak över huvudet ser ut - så är kategorin »de hemlösa» varken självklar eller absolut. Beteckningen hemlös har under olika perioder använts för att sammanfatta mycket olikartade livsvillkor och människoöden. De danska § 105 institutionernas klienter utgör idag en brokig skara som har föga gemensamt med de mest populära stereotypierna på området: vagabonden och "posedamen" ("baglady"). § 105 området kan tragiskt nog betraktas som en gigantisk socialpolitisk avstjälpningsplats dit alla de problem förpassas som inte passar in i några andra sociala system.

Den s.k. nya hemlösheten återspeglar inte nödvändigtvis en faktisk ändring i grupperna av socialt utslagna. Den har, menar jag, först och främst sin förankring i strukturförändringar på institutionsområdet och i en professionell retorik vars huvudsakliga mål är att plädera för ökade resurser.

\section{Hemlöshet och fattigdom}

Internationellt sett är föreställningen om en feminisering av hemlösheten en direkt följd av diskussionen om en feminisering av fattigdomen (jfr. t.ex. Stoner 1983, Burt \& Cohen 1989). Sistnämnda begrepp myntades på 1970-talet i USA (Pearce 1978) för att beskriva att andelen kvinnor var stigande bland socialbidragstagare och andra grupper av fattiga. Kärngruppen bland dessa "nya fattiga" var familjer med en kvinnlig ensamförsörjare.

Danmarks hemlösa kvinnor är i vid utsträckning ensamförsörjare. I en landstäckande rapport om $\S 105$ området (Amterne og videreudvikling... 1990) beräknades antalet klienter (= personer inskrivna den 11.4.1989) till ca 2200.20 procent av dessa var kvinnor och hälften av dem hade barn med sig på institutionen. Av de 40 kvinnor jag intervjuade hade 60 procent barn och den absoluta majoriteten av dessa kvinnor var ogifta, frånskilda eller separerade.

Den internationella forskningslitteraturens beskrivningar av nyfattigdom bland ensamförsörjare kan givetvis inte direkt tilllämpas på hemlösa kvinnor i Köpenhamn. Kvinnliga ensamförsörjare i Norden har, som rapporterats i flera studier, bättre ekonomiska villkor än ensamförsörjare i många andra länder. I en internationell undersök- 
ning av ekonomiska problem i olika befolkningsgrupper har man t.ex. räknat ut att endast 9 procent av de svenska ensamförsörjarna skulle falla under den amerikanska fattigdomsgränsen, medan ca hälften av de amerikanska ensamförsörjarna gör det (Smeeding \& Rein 1988, citerat i Goldberg \& Kremen 1990).

Inte desto mindre befinner sig kvinnliga ensamförsörjare i en utsatt socioekonomisk position också i Norden. Ivan Thaulow och Birthe Gamst (1987) påvisar t.ex. att kvinnliga ensamförsörjare i Danmark i mycket hög grad är beroende av socialhjälp: på årsbasis mottar ca 40 procent av ensamförsörjarna ekonomisk hjälp. Arbetslöshet och bostadsproblem är speciellt vanliga bland kvinnliga ensamförsörjare. 27 procent av kvinnorna i Thaulow \& Gamsts undersökning var arbetslösa mot 2 procent av de manliga ensamförsörjarna. $2 / 3$ av ensamförsörjarna bodde i hyresbostad; motsvarande andel bland alla danska barnfamiljer är ca 20 procent. Den ngenomsnittliga ensamförjaren" i socialhjälpssystemet beskriver Thaulow \& Gamst som: „en kvinde på 34 år med ét barn på 8 år. Hun er fraskilt... Inden for de seneste fem år har hun haft næsten uafbrudt kontakt med bistandskontoret. Hun er arbejdsløs, uden erhvervsuddannelse og har et svagt socialt netværk»(Thaulow \& Gamst 1987, 17).

Intressant nog kan denna beskrivning av "genomsnitts-ensamförsörjaren" nästan ordagrant tillämpas på de hemlösa kvinnor jag har intervjuat. Majoriteten av de 40 har ingen utbildning efter grundskolan och en stor del av dem har direkt från skolan kommit ut i 1970- och 80-talens ungdomsarbetslöshet. Om man därtill lägger det fak- tum att över hälften av kvinnorna är (och att andra kvinnor tidigare varit) ensamförsörjare klarnar bilden av en socioekonomiskt mycket sårbar grupp. Vägen ut i fattigdom och hemlöshet har inte varit särskilt lång för dessa kvinnor.

Ett tema som återkommer i intervjuerna i min undersökning är att det är svårt att finna adekvat hjälp då man står i en situation med akut fattigdom och bostadslöshet. Det är inte lätt att hitta rätt i den köpenhamnska 105 djungeln. I följande citat berättar en av de intervjuade kvinnorna om sina svårigheter att få hjälp, då hon, gravid, bostadslös och lågavlönad, vände sig till socialförvaltningen:

Jeg blev sagt op... og havde to måneder til og finde noget andet og bo i, og det kunne bare ikke lade sig gøre... Så jeg henvendte mig på socialcentreret, og de ville ikke hjælpe mig, fordi jeg arbejder... Hun sagde bare at jeg selv måtte finde ud af det... Jeg skulle rende rundt og søge lejligheder. Så sagde jeg, jamen det har jeg gjort. Og hvad hvis jeg får en lejlighed, sagde jeg, jeg har ikke penge til det indskud, kan jeg få hjælp til det... Nej, fordi når jeg gik på arbejde, så måtte jeg jo snakke med min bank. Så hvad hvis min bank siger nej, jamen det kunne de ikke gøre noget ved. Så var jeg stillet ligesom alle andre, der gik på arbejde... Så jeg følte mig lidt som "Palle alene i verden" lige pludselig. Ikke noget sted og bo og... gravid... Jeg var ligesom ikke noget... Og det gik mig meget på, at jeg vidste at lige pludselig skulle jeg stå på gaden, hvis det var« (G, 28 år, ett barn).

G hittade så småningom ett pensionat för ensamförsörjare. Det är en institution där föräldrar och barn kan bo (i ett litet rum med kokvrå och badrum) i maximalt tre år. Det finns en socialarbetare i huset, som har 
100 lägenheter. Socialarbetaren hjälper familjerna med kontakter med olika myndigheter, bostadsförmedling, barninstitutioner osv., men ett grundkrav är att familjerna skall kunna klara sig själva. Nästan samtliga familjer i huset har en kvinnlig ensamförsörjare.

Ensamförsörjarfamiljer som hankar sig fram i samhällets utkant är inte ett nytt fenomen. Det som är nytt för danska ensamförsörjare är att de kommit in under § 105 institutionernas ansvarsområde. Av de institutioner i Köpenhamns kommun som har övergått i § 105 regi sedan 1976, vänder sig två tredjedelar till kvinnor och/eller familjer. En stor del av § 105 områdets differentiering och modernisering under 1980-talet hade ett samband med att familjeinstitutionerna (och »krisecentren", jfr senare) har dragits in i hemlöshetssektorn. Det är därför inte så konstigt att andelen kvinnor och barn har ökat i hemlöshetsstatistiken.

Fattigdom bland kvinnor - och speciellt bland kvinnliga ensamförsörjare, kvinnovåld och problematiska föräldra-barn relationer är de variabler som skiljer de nya $§ 105$ institutionerna från de gamla (Jfr Amterne og viderudvikling... 1990, Arskog m.fl. 1990). Bl.a. har man byggt en helt ny typ av institutioner, vanligen en kombination av ett mindre antal dygnplatser (tre till fem dygn) och ett större antal ambulerande familjekontakter. De problem som dessa familjecentrer betraktar som sitt huvudsakliga ansvarsområde är: uppfostringsproblem, relationsproblem mellan föräldrar, och mellan föräldrar och barn, personliga problem hos föräldrarna, ensamhet, ångest osv. Ett centralt mål är att förebygga tvångsomhändertaganden av barn - eller, om ett tvångsomhän- dertagande blir nödvändigt, att lindra konsekvenserna av det. Den absoluta majoriteten av familjerna på dessa centrer är familjer med en kvinnlig ensamförsörjare.

Centrernas inriktning har inneburit att § 105 sektorn har utvidgats med ytterligare ett verksamhetsområde, som är mycket oklart i konturerna. Man kan här dra en parallell till den amerikanske forskaren Kim Hoppers (1990) beskrivning av hemlöshetsinstitutioner som en sorts hybrid-institutioner. Hemlöshetsinstitutionernas funktion är att samla upp problem som inte "passar in" i andra hjälpsystem. Dagens härbärgen och kriscentrer opererar i gränslandet till forna tiders fattigvård, och har funktioner som ingen riktigt kan placera: att ta hand om kriser, konflikter, splittring m.m. (ibid).

De kvinnliga ensamförsörjarnas problem blev under 1980-talets lopp effektivt synliggjorda. Det var inte bara deras ekonomiska problem välfärdssamhället skulle ta ansvar för utan också deras psykosociala problem. I sin bok Governing the soul beskriver den brittiske forskaren Nikolas Rose (1990) utvecklingen på institutionsområdet, inte som en överföring av funktioner från familjelivet till välfärdsinstitutionerna, men som ett försök att "göra familjen ansvarigu. De preventiva interventionernas mål är att lära de vuxna familjemedlemmarna - i praktiken ofta den kvinnliga ensamförsörjaren - att uppfostra, sätta gränser och uppoffra sig (ibid).

Därmed inte sagt att de kvinnliga ensamförsörjarna på det danska § 105 området inte skulle behöva hjälp. I följande citat berättar en kvinna om sina problem att finna ett ställe att bo i samband med en skilsmässa - och om sitt första möte med en $\S$ 105 institution: 
Så på et tidspunkt, hvor jeg havde snittet mig i håndledet... så gik jeg så op og fortalte min læge, hvordan jeg havde det. Der blev han jo dødchokeret og henviste mig... ja i første omgang til daghospital, men de ville ikke have mig, fordi jeg havde for mange problemer og var sådan terapeutisk udenfor rækkevidde... Så fik jeg så en henvisnig til en psykiater, men hende skulle jeg vente på et halvt år, så jeg fik noget antidepressivt medicin... Og jeg havde så været inde og snakke med socialrådgiveren, om ikke der var et eller andet sted, jeg kunne bo... men det eneste hun sådan kendte til, det var Kvindehjemmet... men der skulle man være psykisk meget stærk for at bo...

Så var jeg så ude og kigge på noget... et herberg... det skulle sådan mere eller mindre være det eneste sted, der var... ifølge min socialrådgiver... Og det var så frygteligt, at vi tænkte, at hvis jeg skal bo der, så dør jeg simpelthen... Og jeg tænkte min søn, han bliver dødchokeret... Han er 6 år altså... Jeg syntes virkelig, det var et frygtelig sted» (S, 36 år).

Vid tidpunkten för intervjun bodde den här kvinnan på ett pensionat för hemlösa kvinnor och män i Köpenhamn. Med sig på pensionatet hade hon sitt yngsta barn, hennes andra barn bodde hos pappan. S. hade just fått information om att hon skulle få flytta ut i ett kollektiv tillsammans med några andra hemlösa.

\section{Hemlöshet och kvinnovåld}

1980-talet var alltså den period då ensamförsörjarnas problem fördes upp på den socialpolitiska dagordningen. Ett annat familjeproblem som uppmärksammades under 1980-talet var kvinnovåldet.

Den kvinnliga hemlöshetens starka samband med våld överraskade mig i undersökningens början. I intervju efter intervju, på alla typer av § 105-institutioner (härbärgen, familjeinstitutioner, kriscentrer), berättade kvinnorna om våldshandlingar, som deras manliga sambor utsatt dem för. Vill man utpeka en specifik faktor, som kan förklara den ökade andelen kvinnor i hemlöshetsstatistiken, så skall man utan tvivel välja familjevåldet. Därmed inte sagt att våldet skulle ha ökat. Kvinnomisshandel i Danmark är, menar jag, nu blott registrerat på ett sätt som var otänkbart tidigare.

Kvinnogrupper och »krisecentrerbevegelsen" har - utifrån 1970-tals devisen "det personliga är politiskt» - lyckats föra upp kvinnovåldet på den socialpolitiska agendan. Från att tidigare ha varit ett dolt fenomen, har kvinnovåldet idag blivit definierat som ett socialt problem (se t.ex. Christensen \& Koch-Nielsen 1992). Genom upprättandet av en rad kriscentrer i landet, och genom införandet av dessa centrer i bl.a. biståndslagens § 105 regi, har kvinnovåldet, åtminstone delvis, kopplats loss från sin exklusiva status som ett privat fenomen.

Också i andra länder har man konstaterat att den "nyau kvinnliga hemlösheten sammanhänger med ett synliggörande av våldsproblem (jfr t.ex Peroff 1987). Den amerikanska sociologen Nanette J. Davis (1988) har beskrivit synliggörandet av kvinnovåldet som en process med tre stadier: traditionell struktur, dekonstruktion och rekonstruktion. Under den första fasen var familjevåldet definierat som en absolut privat angelägenhet. Doktrinen om separata sfärer - en manlig offentlig och en kvinnlig privat - var dominerande. Kvinnomisshandel var inte något som diskuterades i offentligheten. Under den andra fasen, som enligt Davis inföll på 1960- och 70-talen, 
skedde det en gradvis dekonstruktion av kvinnovåldets sociala innebörd. Parallellt med kvinnors utträde i förvärvslivet och kärnfamiljens uppluckring, upplevde många västländer en tilltagande offentlig debatt och forskning om kvinnovåld. Den tredje fasen, som sträcker sig från 1980-talet fram till idag, kännetecknas av konsolidering och ökat statligt ingripande. Från att tidigare ha varit ett ärende för kvinno- och kriscentrarörelsen har kvinnovåldet accepterats som ett socialt problem som välfärdsstaten bör åtgärda (ibid).

I takt med de- och rekonstruktionen av kvinnovåldet har det samlats en hel del administrativa och forskningsmässiga uppgifter om våldets utbredning och karaktär (se t.ex. Hanson Frieze \& Browne 1989, Christensen \& Koch-Nielsen 1992). Den danska Sundhedsstyrelsen, räknar med att det årligen på landets "skadestuer" behandlas ca 20 000 kvinnor för skador relaterade till våld och att ca 60 procent av dem har utsatts för valld i hemmet (Rapport om vold mod kvinder i Danmark 1992, 26). Polisen rapporterar att antalet anmälda våldshandlingar mot kvinnor var ca $4800 \mathrm{i}$ hela landet år 1990, därtill kommer ca 15000 polisutryckningar till "husspektakler" (ibid, 13). Från Socialministeriet uppges att man i slutet av 1980-talet kunde registrera en kraftig ökning $i$ antalet hänvisningar till landets kriscentrer (det fanns 34 sådana år 1990). Under år 1990 övernattade 2200 kvinnor och drygt 2000 barn på något av de 28 undersökta kriscentren, och 88 procent av kvinnorna hade med säkerhet varit utsatta för fysiskt våld eller hot om våld (Christensen \& Koch-Nielsen 1992).

Av de 40 kvinnor som intervjuats i min undersökning uppger 26 ( 64 procent) att de utsatts för våld från en aktuell eller tidigare sambos sida. Ytterligare tre kvinnor säger att de utsatts för hot om våld, och tre kvinnor beskriver sitt äktenskap i termer av "psykisk terrorı. Vid flertalet tillfällen har våldet ett direkt samband med kvinnornas hemlöshetssituation. Ungefär hälften av samtliga intervjuade har flyttat till kriscentret, härbärget eller pensionatet som en följd av misshandel eller våldshot.

Kvinnors toleranströskel, då det gäller familjevåld, återspeglar givetvis de till vår tid rådande sociala konstruktioner av vad ett normalt familjeliv är och bör vara. Utländska attitydundersökningar tyder på att inställningen till familjevåld har ändrats i befolkningen. Från 1970-talet till 80-talet kunde man bl.a. i USA se en tendens mot ökat avståndstagande till kvinnomisshandel (Frieze \& Browne 1989). Också i Danmark tycks de senaste femton årens offentliga debatt om familjevåld, tillsammans med utbyggnaden av ett krisecentrernät, ha ruskat om föreställningen om familjevåld som något kvinnor får lov att leva med (härom vittnar t.ex. Justitsministeriets rapport om våld mot kvinnor 1992). Den offentliga debatten kan ha minskat kvinnornas barriärer mot att söka hjälp; familjevåld har i högre grad än tidigare blivit definierat som en legitim orsak till separation och skilsmässa.

Därmed inte sagt att våldsdrabbade kvinnor idag får den hjälp de behöver. Vägen från en våldsrelation till ett krisecentrer eller härbärge kantas av många hinder, av emotionell, kulturell och praktisk art. Kvinnornas svårigheter då det gäller att be om/söka hjälp sammanhänger bl.a. med följande tre förhållanden. 
För det första upplever de intervjuade (fortfarande) att deras problem inte tas på allvar av myndigheterna. Våldsepisoderna blir definierade som familjegräl och whusspektakler" - ett begrepp som flera intervjuade tar kraftigt avstånd från. Från polisens sida betraktar man fortfarande "medling" mellan parterna som den viktigaste arbetsuppgiften i samband med familjevåld (Rigspolitichefen 1992, s.79), något som kan verka överraskande i ljuset av de senaste tio årens debatt om kvinnovåld. Det är inte en medling kvinnorna behöver - detta framhålls av många intervjuade - utan det motsatta: en hjälp i att ta situationen på allvar, en bekräftelse på att misshandel inte kan accepteras, ett fasthållande av att "vold ikke ties ihjæl« (Christensen 1984).

För det andra har en del av de intervjuade en generell misstro mot myndigheter. De utgår från att deras situation förvärras om de upplyser socialarbetaren, polisen eller sjukhuset om sina problem. Om myndigheterna får insyn $i$ familjens problem kan det, enligt kvinnorna, t.ex. leda till att barnen tas hemifrån, eller till direkta hämndaktioner från mannens sida.

För det tredje upplever kvinnorna att myndigheternas åtgärder är verkningslösa. Trots att de sökt - och i vissa fall fătt - hjälp hos polis och socialarbetare, så känner de sig både skyddslösa och rättslösa. Hade jag tidigare varit osäker på om våldsdrabbade kvinnor som bor på $\S 105$ institution faktiskt skulle definieras som hemlösa, så var jag det inte längre då jag hörde dessa kvinnor beskriva sin situation. I följande citat berättar en kvinna om sina upplevelser med en exmake som förföljer henne. Kvinnan har i ett par års tid flyttat från adress till adress, från institution till institution. Hon är 29 år och bor nu på ett härbärge med sina tre barn som är 1, 6 och 10 år gamla:

Jeg bor her... fordi jeg har blevet slået ned af mit barns far... Sidste gang... slog han mig ned, så jeg var bevidstløs... Han havde fundet mig via, at vi skulle i retten... I to år har han fundet mig sådan rundt omkring... Og det er også grunden til, at jeg har boet på krisecentrer i Lyngby... Så fandt jeg så en fremleje i X med c/o adresse og hele mulevitten og tænkte det er helt fint, her kan du sagtens være... Så vidste han jo, hvor børnene gik $i$ institution - det fortsatte de med - og så var det jo ikke ret svært at finde ud af, hvor jeg var. Så flyttede jeg så ind på Grevinde Danner og boede der til efter jeg havde født... Og så flyttede jeg til $Y$, fordi jeg er opvokset der, og har hele tiden søgt om, at komme tilbage. Og der har jeg så boet indtil han fandt mig igen... Og så nu denne gang, der valgte jeg så, at tage herind. Problemet er jo nu, at jeg har en lejlighed. Altså jeg sidder jo reelt på en lejlighed. Betaler husleje hver måned til en lejlighed, der står tom... 4000 ,- Jeg tør bare ikke bo i den lejlighed.. Jeg kan jo ikke bruge den... andet end til møblerne, de står der jo. Så jeg syntes det er en lidt dyr opmagasinering.

Det er næsten to år nu, hvor jeg har kartet rundt - fået lov til at være et stykke tid i min lejlighed og så... Jeg har haft det så dårligt med det - er gal, gal over det danske retssystem. Gal over det er mig, der skal flytte mine børn væk fra deres vante omgivelser, og så at politiet faktisk er magtesløse og ikke kan gøre noget» ( $L, 29$ år).

Den här kvinnan har inte mycket gemensamt med den traditionella bilden av hemlösa och socialt utslagna. Hon tillhör inte gatans hemlösa. Hon har inte en bakgrund präglad av dåliga uppväxtförhållanden, social marginalisering och missbruksproblem. Hon har heller ingenting gemensamt med "posedamernau, den främsta stereotypin då 
det gäller kvinnlig hemlöshet i Danmark. Inte desto mindre är hon hemlös; hon känner sig förföljd och utsatt och har ingen annan möjlighet än att bli boende på härbärget.

\section{Om $§ 105$ områdets normaliseringmodell}

Som framgått hittills består den s.k. nya kvinnliga hemlösheten i Danmark bl.a. av ensamförsörjarproblem och våldsproblem. Dessa två problemkomplex har införlivats $\mathrm{i}$ det sociala system som namngivits av biståndslagens $§ 105$. Vad innebär då detta i praktiken för de kvinnor som skrivs in på institutionerna?

I Socialministeriets cirkulär om institutioner under amtskommunerna fastslås vissa målsättningar på $\S 105$ området (cirkulære 17.12.1986, § 86 om formålet med forsorgshjem m.v.). Det konstateras att institutionerna genom behandling, omvärdering och omsorgsfunktioner skall eftersträva, att klientelet skall kunna återvända till arbetslivet, eller "till andra hjälpformer utanför institutionen«. Biståndslagen ställer inga krav på vilka behandlings- och sysselsättningsmöjligheter som skall erbjudas klienterna. Lagen specificerar blott att winstitutionerne skal være egnede til at modtage hjemløse og personer, der ikke kan tilvænne sig det almindelige samfundsliv" (cir. 17.12.1986, \& 87 om oprettelse af forsorgshjem m.v.).

Hemlöshetsinstitutionerna utgår - i likhet med andra institutioner för "sociala avvikare« från en normaliseringsmodell (jfr Foucault 1965). De utgör ett socialt system som upprätthålls genom definitioner, klassi- ficering och behandling av de hemlösa. Normaliseringsprocessens konkreta innehåll har sett olika ut vid olika tidpunkter och den tar sig också olika uttryck på olika hemlöshetsinstitutioner.

Den överordnade normaliseringsmodellen på § 105 området innehåller dock tre huvudelement (jag följer här delvis Jokinen \& Juhila 1991). Det första sammanhänger som termen normalisering indikerar - med det faktum att de hemlösas liv inte uppfyller de kriterier på livskvalitet som är rådande i samhället. Hemlösheten betraktas som en absolut motpol till ett gott och tryggt liv. Den analyseras sällan som ett renodlat bostadsproblem (eller våldsproblem); de berörda antas ofta vara avvikande också i andra avseenden. Normaliseringsmodellen sammanhänger med stämpling. De hemlösa är, per definition, personer som inte kan anpassa sig. De är också ofta omgivna av en ansenlig mängd fördomar och misstänksamhet - kanske mera utanför institutionerna än inom $§ 105$ sektorn.

Det andra momentet i normaliseringsmodellen är mydighetskontroll. De hemlösa beskrivs ibland som "fria fåglar", personer utan förpliktelser - och rättigheter, personer som står utanför samhällsgemenskapen. Faktum är dock att de flesta hemlösa har en nog så intensiv kontakt med olika sociala instanser och myndigheter. Många hemlösa lever i ett "socialadministrativt landskap", där de ständigt tvingas förhandla med det sociala systemet - bl.a. för att få ekonomisk hjälp och tak över huvudet till natten.

Som ett tredje moment i normaliseringsmodellen har man nämnt cyklicitet/kretsgång. Med all respekt för § 105 områdets hjälparbete, kan man ändå konstatera att ett 
egentligt resocialiseringsmål ofta är utopiskt. De svagaste bland de hemlösa har med nuvarande hjälpresurser - små chanser att komma bort från det som kallats bostadsmarknadens bottenskikt (Jokinen \& Juhila 1991). De växlar mellan olika hemlöshetsinstitutioner, vårdinstitutioner, och boende i den sämsta och billigaste delen av bostadsmarknaden. Stämplingen och myndighetskontrollen upphör inte nödvändigtvis för att en institutionsboende flyttar ut i en egen, usel lägenhet.

Då det gäller elementen stämpling, myndighetskontroll och cyklicitet på § 105 området, så kan man säga att tonen är angiven redan i själva lagtexten. Den danska biståndslagens $\$ 105$ definierar (jfr tidigare) sin målgrupp som "personer, der er hjemløse eller ikke kan tilvænne sig det almindelige samfundslivu. Man kan fråga sig om denna beskrivning faktiskt passar in på de personer (t.ex. fattiga ensamförsörjare och misshandlade kvinnor) som söker hjälp på § 105 institutionerna idag.

Att $\S 105$ institutionerna är förbundna med ansenliga stämplingsmekanismer vet både personal och klienter. Följande citat är hämtade ur mina intervjuer med personalen på några av de största institutionerna i Köpenhamn. De första citatet handlar om stadens största och äldsta kvinnohärbärge, det andra om ett pensionat för ensamförsörjare, det tredje om ett kombinerat aktivtets- och boendecentrer som mottar både män och kvinnor:

Mange kvinder er rædselsslagne, de er meget ulykkelige da de skal ind her, fordi Kvindehjemmet, det er det sidste skridt nedad, så kan man ikke komme længere (Lederen for Kvindehjemmet på Jagtvej).
Vi ved for eksempel at der er nogen forretninger i kvarteret der ikke vil sælge på afbetaling hvis man har adresse her... Vi har lidt dårligt ry... Vores gamle direktør, som nu er død, fortalt selv en historie om at komme op i en taxa og sige adressen her og så chaufføren der siger. 'nå, det er der man kører damer hen om dagen og herrer om natten (Lederen for Egmontgården på Østerbro).

Kofoeds Skoles image er et problem... Vi holder mange møder med sagsbehandlere som siger at, jamen derind kan vi da ikke få folk at komme... Og det må være ganske angstfremkaldende for kvinder da de kommer første gang og ser den gruppe mænd der nede. Kofoeds Skole har da også fra gamle dage en status som heder bunden. Man tænker at til Kofoeds Skole der kommer de dårligste af de dårlige (Socialrådgiver på Kofoeds Skole).

\section{$\S 105$ institutionernas klienter har inte hög} status ute i samhället. Flera av de intervjuade kvinnorna berättar t.ex. om hur svårt det är att gå ut och söka ett arbete, och så vara tvungen att uppge ett härbärge eller ett pensionat som sin hemadress. V, 48 år, som har bott på ett pensionat i två år, säger:

Jeg er slet ikke bange for at tage fat på noget, og jeg er heller ikke bange for andre mennesker... Men man føler alligevel, det er et nederlag, at man bor sådan et sted. Jeg bryder mig ikke om, at opgive adressen andre steder, eller gå ud og søge et job, og skal opgive en adresse på det på det herberg der... Det har jeg godt nok gjort, men de kigger sådan lidt medlidende på en, og smiler sådan. Vi skal nok skrive til dig, og jeg ved jo udmærket godt, at jeg aldrig får svar... Sådan et medlidenhadssmil der altså.... de kunne lige så godt sige med det samme, nej tak det har ikke nogen interesse... fordi deres medlidenhed, den kan man ikke bruge til noget “ $(\mathrm{V}$, 48 år). 


\section{Behandling eller förvaring?}

Kvinnornas situation på institutionerna försvåras också av att hela $\S 105$ områdets verksamhetsprofil är mycket oklar. Det har under de senaste åren förts en diskussion om huruvida § 105 institutionerna skall erbjuda behandling eller inte. I en rapport från en $§ 105$ planeringsgrupp under Köpenhamns kommun kan man utläsa en betydlig ambivalens på denna punkt. $\AA$ ena sidan konstaterar arbetsgruppen att man inom $\S$ 105 sektorn löpande har företagit justeringar från rena omsorgsfunktioner till "socialpedagogiska, målinriktade och rehabiliterande åtgärder", dvs. att institutionerna blivit mer och mer behandlingsinriktade (Rapport vedrørende de københavnske $\S 105$ institutioner 1991, 9). $\AA$ andra sidan skriver man explicit att $§ 105$ institutionerna inte skall vara behandlingsinstitutioner, men att de utöver sin basala boendefunktion skall vara kontaktförmedlande i förhållande till behandlingssystemet. Senare i rapporten konstaterar man att framtidens "basinstitutioner" på $§ 105$ området skall erbjuda: rådgivning och vägledning, omsorg, motivationsarbete osv. Allt detta är funktioner som en del $§ 105$ institutioner erbjuder idag, och som flera av de intervjuade institutionsrepresentanterna definierar som "behandlingu. Ambivalensen är emellertid tydlig också på institutionerna.

"Hjælp til selvhjælp« är ett gammalt och vedertaget begrepp (bl.a.) på danska hemlöshetsinstitutioner. Begreppet återkommer, om man ber personalen beskriva institutionernas verksamhetsprofil. Fenomenet hjälp till självhjälp har dock mycket olika innehåll på olika institutioner, och i många fall kan personalen inte redogöra för begreppets innebörd. Relationen mellan detta begrepp och t.ex. behandling och resocialisering är oklar. Oenigheten är också stor då det gäller den traditionella icke-behandlingsprincipen på institutionerna. Representanterna för de gamla och stora institutionerna håller ofta fast vid denna princip, medan personalen på en del av de små institutionerna menar att den blockerar för modernisering. De menar att icke-behandlingsmodellen i praktiken fungerar som legitimering för en ren laissez-faire hållning från personalens sida. Klienterna erbjuds tak över huvudet på institutionen men absolut ingenting annat.

Det kan på denna punkt vara relevant att dra en parallell till Lars Lindströms (1992) diskussion om omsorg och rehabilitering på svenska behandlingsinstitutioner. Lindström har analyserat hjälparbetet bland hemlösa missbrukare med utgångspunkt från institutionernas "manifesta" och "latentau målsättningar. Han menar att det på de flesta institutioner manifesta målet, att rehabilitera de hemlösa till ett normalt liv i samhället, är orealistiskt. En stor del av de hemlösa kan inte leva upp till detta mål, enligt Lindström, vilket leder till frustrationer både bland personal och klienter. Institutionens lösning på dilemmat blir ofta att man försöker gallra bort det svagaste klientelet, de mest "hopplösau fallen. För att uppnå den eftersträvade resocialiseringen försöker man satsa på de mest resursstarka klienterna. Vad man i stället borde göra, menar Lindström, är att erkänna det latenta, och betydligt mera realistiska, målet: att erbjuda de hemlösa - också de svagaste bland dem - omsorg och en människovärdig tillvaro på institutionen. Hemlöshetsinstitu- 
tionerna måste godta att det näst bästa kan vara gott nog (ibid).

Lindström har givetvis rätt då han drar slutsatsen att omsorgssystemet bör vara så rymligt att det kan omfatta också de svagaste och minst "rehabiliterbara" klienterna. $\AA$ andra sidan är det slående hur stora olikheter det finns mellan det svenska och det danska hjälpsystemet på hemlöshetsområdet. I Köpenhamn råder det ingen brist på omsorgsinstitutioner av den lågtröskelmodell som Lindström efterlyser. Det är institutioner där det inte ställs några som helst krav på de inskrivna.

Bland de 40 kvinnor jag har intervjuat är lågtröskelinstitutionerna dock de minst populära (huruvida detta är fallet bland alla Köpenhamns hemlösa vet jag givetvis inte). Den helt avgörande faktorn i kvinnornas betygssättning av § 105 institutionerna var nämligen dimensionen behandling - icke-behandling. Ju mera behandlingsinriktad verksamheten på institutionerna var desto nöjdare var klienterna. Psykolog- och psykiaterhjälp, gruppsamtal och andra sociala aktiviteter, socialarbetar- och socialpedagoginsatser - allt detta var mycket populärt. Ju mera kontakt personalen hade med klienterna desto bättre betyg fick institutionen av kvinnorna. En aktivt stödjande insats från personalens sida (och detta är ingen självklarhet på danska 105 institutioner), då det gäller kontakter med bl.a. daginstitutioner, socialförvaltningen och vårdsystemet bedömdes som mycket viktig. Kvinnorna upplevde då att personalen backade upp dem och stod på deras sida i de många gånger besvärliga förhandlingarna med olika myndigheter.

De institutioner som får mest kritik av de intervjuade är de som bara, eller primärt, erbjuder boende. Det finns institutioner där man, enligt kvinnorna, inte kan förvänta sig någon som helst hjälp från personalens sida. En kvinna som bor på en sådan institution, ett pensionat som drivs av Köpenhamns kommun, säger följande om klienterna på pensionatet:

De kommer grædende og er meget dårlige nerver, de hænger faktisk i laser. Det de trænger til, det er først at få lov til at komme i bad og få noget andet tøj på og så... snakke med nogen ikk'... Det er der bare ikke noget af her... Jeg syntes virkelig der skulle være noget mere hjælp... Det kan ikke nytte noget at det er til i morgen at sagsbehandleren har tid, og så har hun heller ikke tid alligevel... Det er det, jeg syntes, er så forfærdeligt. At der virkelig ikke er nogen, der har 5-10 minuter en gang... Gør dit - gør dat - ja, men det må du virkelig selv om. Det er i det hele taget på den måde der... Så lige pludselig en dag, så kommer de, så banker de på, farvel nu rejser vi. Ja, hvor har du fået noget at bo i? Næ, de tager tilbage igen, hvor de kom fra. De magtede ikke og komme ud af den suppedas, når de så også kommer sådan et sted som her... Om man bare kunne få nogle samtaler... en førstehjælp... Så man forstår at man ikke er helt ude af systemet, fordi man ender sådan et sted vel (V 48 år).

En annan kvinna säger följande, om samma institution:
Det er svært når man er kommet og endt så- dan et sted, som her... for der er ingen hjælp og hente her... Tværtom, så bliver du jordet... af dem, der er ansat her. Det gør du. Hvis ikke du er stærk nok til at sige noget igen... Sådan er det gennemgående... Jeg har set det mange gange... set hvordan folk blir behandlet her.. jeg kan godt forstå, de føler.. sidder og græder over det. Og de ansatte er komplet kolde... Kommunen de øder så mange penge... de øder simpelthen så mange penge væk til alt mulig 
ting og sager... men de vil sørensusme ikke få det menneske op og stå igen, som de har kaldt en social taber... Det syntes jeg er noget af det mest nedværdigende... Og så bliver det nok sådan at de mennesker her de sidder og tænker på, nå ja når jeg alligevel ikke bliver betragtet som noget som helst, så kan det jo også være ligemeget altsammen ikk'... (S 35 år).

I stället för att fungera som kontaktled till resten av samhället fungerar alltså vissa $\S$ 105 institutioner definitivt som wändstationer". Vistelsen på institutionen blir ytterligare en bekräftelse på att klienterna är utslagna.

Avslutningsvis: Syftet med denna artikel har varit att analysera den s.k. nya hemlösheten utgående från upplysningar om en grupp hemlösa kvinnor i Köpenhamn. Jag har hävdat att den "nya» hemlösheten inte nödvändigtvis återspeglar ändringar i hemlöshetspopulationen. Att andelen hemlösa kvinnor idag är större än tidigare har ett samband med ändrad statistikföring på området och med att flera och flera institutioner kommit in $\mathrm{i} \S 105$ regi. Två problemkomplex har härmed synliggjorts: a) kvinnliga ensamförsörjare med sociala och ekonomiska problem, samt b) kvinnovåld. Dessa två fenomen blev under 1980-talet definierade som socialpolitiska problemområden som skulle åtgärdas. Nya institutioner upprättades, dessa införlivades i § 105 sektorn och medförde att persongrupper som för femton år sedan inte skulle ha definierats som hemlösa idag ingår i hemlöshetsstatistiken. Denna utveckling har i artikeln använts för att illustrera hemlösheten som "social konstruktion". Hemlöshet är inte ett självklart, absolut eller statiskt begrepp. Det är ett socialt fält som är öppet och som ständigt rekonstrueras. Den danska § 105 sektorn är mycket oskarp i konturerna och har ofta fått fungera som social avstjälpningsplats för problem som inte passar in $\mathrm{i}$ andra sociala system.

Man kan fråga sig om $\S 105$ institutionerna faktiskt är de rätta att ta hand om "de nya hemlösau, dvs. kvinnor, ofta med barn. Institutionerna har ursprungligen uppstått för att tackla andra typer av problem än dem som beskrivits i denna artikel. Deras grundläggande verksamhetsmodell bygger på föreställningen om bostadslösa män (vagabonder, lösdrivare) som behöver tillfälligt nattlogi. Kvinnorna på § 105 området idag har nästan ingenting gemensamt med dessa traditionella hemlösa. De gamla stora institutionerna är dåligt rustade att tackla de problem som kvinnliga ensamförsörjare och våldsoffer har. Därtill kommer att hemlöshetsinstitutionerna har mycket låg status och extremt dåliga resurser i jämförelse med andra behandlingsinstitutioner i Danmark. Stämplingsmekanismerna på $§ 105$ området och kretsgången bland klienterna är ytterligare indikatorer på att "de nya hemlösa» borde placeras någon annanstans än på dessa institutioner. 


\section{Referenser}

Amterne og videreudvikling af \$ 105-institutioner, (1990) Amtsrådsforeningen i Danmark, København.

Arskog, Tove, Marianne Bjørkøe \& Anette Sørensen (1990) Kvinder på vej! Sikon, København.

Burt, Martha R. \& Barbara E. Cohen (1989) „Differences among Homeless Single Women, Women with Children, and Single Men." Social Problems 36, 508-524.

Christensen, Else (1984) Vold ties ikke ihjel. En bog om vold mod kvinder i parforhold. Nyt Nordisk Forlag Arnold Busk, København.

Christensen, Else \& Inger Koch-Nielsen (1992) "Vold ude og hjemme. En undersøgelse af fysisk vold mod kvinder og mænd." Socialforskningsinstituttet, rapport 92:4, København.

Dear, Michael J. \& Jennifer R. Wolch (1987) Landscapes of Despair. From Deinstitutionalization to Homelessness. Polity Press, Cambridge.

Foucault, Michel (1965) Madness and Civilization: A History of Insanity in the Age of Reason. Random House, New York.

Frieze, Irene Hanson \& Angela Browne (1989) „Violence in Marriage." Crime and Justice: 18, 201-218.

Goldberg, Gertrude S. \& Eleanor Kremen (1990) "The Feminization of Poverty: Discovered in America."I The Feminization of Poverty. Only in America? Ed. by G. S. Goldberg \& E. Kremen. Praeger, New York, 1-16.

Hopper, Kim (1990) „Public Shelter as a »Hybrid Institution"; Homeless Men in Historical Perspective«, Journal of Social Issues: 46, 13-30. Jokinen, Arja \& Kirsi Juhila (1991) Pohjimmaiset asuntomarkkinat (Bostadsmarknadens botten- skikt). Bostadsstyrelsen, Helsingfors.

Lindström, Lars (1992) „Omsorgen om hemlösa alkoholister - en funktionell analys. I I Hemlöshet $i$ Norden, red. av M. Järvinen \& C. Tigerstedt, NAD-publikation 22, Helsingfors, 195210.

Pearce, Diana (1978) "The Feminization of Poverty: Women, Work and Welfare."Urban and Social Change Review: 11, 26-38.

Peroff, Kathleen (1987) „Who Are the Homeless and How Many Are There? «I The Homeless In Contemporary Society, ed. by R. D. Bingham, R. E. Green \& S. B. White, SAGE, University of Wisconsin, 33-45.

Rapport om vold mod kvinder. (1992) Afgivet af en af Justitsministeriet nedsat arbejdsgruppe om vold mod kvinder. Justitsministeriet, maj.

Rapport vedrørende de Københavnske \$105 institutioner: herberger og forsorgshjem, (1991) Kobenhavn, (stencil).

Rigspolitichefen, Afdeling E (1992) „Informationstjenesten: Analyse af vold mod kvinder i Danmark." Ingår i: Rapport om vold mod kvinder i Danmark, Justitsministeriet, maj.

Rose, Nicholas (1990) Governing the Soul: The Shaping of the Private Self. Routledge, London. Stoner, Madeleine R. (1983) "The Plight of Homeless Women." Social Service Review: 57, 566581.

Thaulow, Ivan \& Birthe Gamst (1987) Enlige forsørgere mellem selvforsørgelse og bistandshjoelp. Socialforskningsinstituttet, publikation 175, København. 


\section{Summary}

\section{On homeless women in Copenhagen}

The aim of this article is to analyse the socalled new homelessness using data about a group of homeless women in Copenhagen. The study is based on interviews with 40 homeless women and interviews with staff (46 staff representatives at a total of 30 institutions for the homeless). The Danish discussion about the new homelessness and a feminization of homelessness is inspired by the corresponding discussion in the USA. One aim of the article is to show that the new homelessness in Copenhagen does not necessarily reflect changes in the homeless population. The fact that the proportion of homeless women is larger today than before is associated with a change in the way statistics are kept and the fact that more and more institutions have come under section 105 (the section of the Danish Social Security Act dealing with institutions for the homeless and socially excluded). Two problem complexes are thereby made visible: (a) single female breadwinners with social and economic problems, and (b) violence against women. These two phenomena were defined during the 1980s as social problem areas which had to be dealt with. New institutions were established and incorporated in the section 105 sector, which meant that groups of people who would not have been defined as homeless fifteen years ago are now included in the homeless figures. One may wonder, however, whether institutions for the homeless really are the right places to look after the "new homeless", that is to say, the women, who often have children. The model for the work of these institutions is often based on homeless men (tramps, vagrants) who need a casual place for the night. Women in the sphere of homelessness have virtually nothing in common with these traditional homeless men. 